\title{
Страны Западных Балкан перед лицом панде- мии COVID-19: политические рекомендации
}

\section{Группа изучения вопросов региональной стабильности в Юго-Восточной Европе}

Консорциум военных академий и институтов исследования безопасности инициативы Партнерство ради мира, https://pfp-consortium.org/

Резюме: Эти рекомендации по выбору политики отражают выводы Первого виртуального совещания «Страны Западных Балкан перед лицом пандемии COVID-19», созванного исследовательской группой Консорциума ПРМ «Региональная стабильность в Юго-Восточной Европе» 28 мая 2020 года. Статья включает ряд реальных предложений для правительств стран Западных Балкан, а также для ЕС, государствчленов ЕС и лиц, принимающих решения в НАТО, о том, как противостоять коронавирусу и вызовам, связанным с безопасностью, в ЮгоВосточной Европе.

Ключевые слова: COVID-19, ситуационный анализ, рекомендации по политике, Албания, Босния и Герцеговина, Косово, Черногория, Северная Македония, Сербия.

\section{Краткое изложение рекомендаций ${ }^{1}$ :}

- Правительствам Западных Балкан (ЗБ) и ЕС: системы здравоохранения должны поддерживаться средствами из объявленного ЕС пакета поддержки в размере 3,3 млрд евро и других западных источников.

1 Эти рекомендации по политике были подготовлены Предрагом Юрековичем (Австрийская национальная академия обороны, Вена) на основе предложений, представленных участниками вебинара. Ценную поддержку в корректуре и верстке оказали Бенедикт Хенселлек и Лиза Тагверчер (Академия национальной обороны Австрии, Вена). Участниками этого вебинара были (в алфавитном порядке): Милена Бешич (Центр демократии и прав человека, Подгорица), Альба 
- Правительствам стран 3Б: государственные средства, выделенные на преодоление кризиса, должны использоваться прозрачно, а любые возможности для коррупции должны быть ограничены.

- Правительствам 3Б, ЕС и Совету регионального сотрудничества $(C P C)$ : менее националистический региональный климат следует использовать в качестве отправной точки для структурированного регионального сотрудничества в борьбе с пандемией, которое также должно поддерживаться Комиссией ЕС и СРС в Сараево.

- Правительствам 3Б: Следует восстановить четкое разделение исполнительной и законодательной властей. Решения конституционных судов, касающиеся мер COVID-19, должны выполняться, а контролирующая роль омбудсменов и НПО должна соблюдаться.

- $\quad$ EC и другим международные субъектам: Следует и дальше укреплять независимость судебной власти, уделяя особое внимание использованию государственных средств во время кризиса. Любое нецелевое использование государственных средств политиками во время кризиса должно быть публично осуждено, это касается и любых других вовлеченных лиц.

- $\quad$ EC и ОБСЕ: Следует усилить мониторинг выборов, а также соблюдать обязательство по свободному освещению в СМИ предстоящих парламентских или местных выборов.

- Специальному представителю ЕС (СПЕС) для ЗБ: СПЕС должен действовать активно, чтобы продемонстрировать серьезную заинтересованность в демократическом развитии региона и внести свой вклад в конструктивное разрешение конфликтов внутри и между отдельными странами ЗБ.

- $\quad E C$ : Следует начать более подотчетную и динамичную интеграционную политику по отношению ко всем странам ЗБ. Безвизовый режим должен быть предоставлен Косово без дальнейших задержек.

- $E C$ : Следует избегать противоречивых сигналов внутри ЕС по важным вопросам консолидации мира (например, Хосеп Боррелл и Мирослав Лайчак о Косово).

Села (Албанский институт международных исследований, Тирана), Филип Эйдус (Белградский университет), Бенедикт Хенселлек, Предраг Юрекович, Сандро Кнезович (Институт развития и международных отношений, Загреб), Магдалена Лембовска (Eurothink, Скопье), Лулзим Печи (Косовский институт политических исследований и разработок, Приштина), Джордже Попович (Белградский фонд политического передового опыта), Дениса Сарайлич (независимый консультант, Сараево) и Марсель Салаи (оперативная администрация Консорциума ПРМ, Гармиш-Партенкирхен). 
- $\quad$ EC и США: Следует обозначить четкую общую линию ЕС-США по диалогу Белград-Приштина и другим ключевым темам региональной консолидации.

\section{Анализ ситуации}

Несмотря на умеренное течение COVID-19 в странах ЗБ на сегодняшний день, эпидемия выявила явные недостатки в устойчивости региональных систем здравоохранения. Кризис показал, что в регионе остро ощущается нехватка медицинских средств защиты и оборудования для реанимации. В обеих сферах существует высокая степень зависимости от иностранных игроков. Отсутствовали планы и меры профилактики пандемии. Ввиду низкой устойчивости систем здравоохранения умеренное течение COVID-19 в ЗБ могло быть достигнуто только с помощью строгих мер в рамках комендантского часа. Они были основаны на частично авторитарных и непрозрачных решениях политиков в обход парламентов и их конституционных прав.

Например, чрезвычайное положение в Сербии было объявлено неконституционным образом с ложным заявлением о том, что парламент не смог собраться для проведения заседания. В разгар кризиса в большинстве стран ЗБ почти полностью игнорировалось верховенство закона и разделение властей. По данным региональных аналитических центров и правозащитных организаций, за этим последовало множество примеров нарушений прав человека, таких как непропорциональное ограничение свободы передвижения, нарушение свободы СМИ и права на справедливое судебное разбирательство. Несмотря на то, что с мая строгие меры были снова ослаблены, есть опасения, что авторитарные структуры могут остаться в силе после окончания COVID-19. Поэтому ожидается, что пандемия еще больше снизит демократические стандарты на парламентских или местных выборах, запланированных на этот год в Боснии и Герцеговине (БиГ), Черногории, Сербии и Северной Македонии.

Однако, подобно тому, что происходило во время стихийных бедствий, государства ЗБ продемонстрировали во время пандемии, что они в принципе способны преодолеть националистические противоречия во время кризисов. Обнадеживающим знаком в этом отношении стало сотрудничество между медицинскими учреждениями из Сербии и Косово во время пика коронакризиса. Пандемия не должна использоваться как предлог для дальнейшего затягивания процесса расширения ЕС. Таким образом, «зеленый свет» ЕС, полученный Албанией и Северной Македонией в конце марта в отношении начала переговоров о членстве и назначения специального представителя ЕС для 3Б, должен быть использован для ускорения процесса интеграции, и укрепления связей между ЗБ и ЕС.

В противном случае многовекторное влияние (Россия и особенно Китай) на ЗБ с возможным негативным влиянием на региональную консолидацию может еще больше усилиться. Вопреки всем реальным фактам, сербское руководство представило Китай как главного международного союзника во 
время коронакризиса, несмотря на пакет поддержки ЕС в размере 3,3 миллиарда евро для ЗБ. Еще одним фактором является отсутствие общей стратегии ЕС и США по важным вопросам консолидации, таким как нормализация отношений между Сербией и Косово.

\section{Рекомендации по политике}

\section{Применительно к Албании}

- Албанскому правительству: Необходимо вкладывать средства, чтобы медицинский персонал оставался в стране. Эти меры должны выходить за рамки простого повышения заработной платы.

- Албанскому правительству: В свете возможной новой пандемии, правила, касающиеся кризиса, должны быть полностью скоординированными и прозрачными, чтобы избежать путаницы и обеспечить их соблюдение.

- Донорам: Поскольку Албания входит в пятерку беднейших стран Европы, ей следует оказывать помощь в плане медицинского оборудовании и средств индивидуальной защиты, обучения и всех других форм медицинской помощи.

- Албанскому правительству: Следует воздерживаться от авторитарных и непрозрачных мер, например, от незаконного сноса Национального театра и непропорционального применения силы частью полиции против протестующих.

- Албанским политическим партиям: Необходимо найти способы достижения консенсуса между двумя партиями в отношении избирательной реформы, что является основным условием межправительственной конференции с ЕС (без которой «зеленый свет» для переговоров ничего не значит).

- Албанскому правительству и оппозиции: Пандемия и сопутствующие меры не должны использоваться в качестве оправдания для продолжающегося отсутствия Конституционного суда и действующего Верховного суда.

\section{Применительно к БиГ}

- Совету министров БиГ: Следует взять на себя более активную роль в определении политики во время пандемии; должна быть координация усилий с властями более низкого уровня и международными организациями. Учитывая возможную вторую волну пандемии, необходимо обеспечить координацию на государственном уровне для согласования мер в каждом государственном образовании и районе Брчко. 
- Парламентской ассамблее БиГ: Не следует соглашаться на подчиненную роль во время пандемии. Следовательно, во время кризиса должны без перерыва проводиться сессии, а заседания - на регулярной основе.

- Институциям БиГ: Существующий план реагирования на случай пандемии в БиГ следует пересмотреть и обновить с учетом опыта, полученного во время текущего кризиса COVID-19. План должен включать конкретные меры по координации и коммуникации, чтобы избежать путаницы и отсутствия ясности.

- Институциям БиГ: Необходимо усилить механизмы борьбы с коррупцией, особенно в отношении государственных закупок. Случаи коррупции, возникшие во время пандемии, должны рассматриваться как можно эффективнее и действеннее, чтобы восстановить доверие общества к институциям.

- Институциям БиГ: Меры, призванные минимизировать все опасности для здоровья населения, следует применять последовательно и без исключений, как это было в случае с некоторыми религиозными учреждениями во время пандемии.

- Властям субъектов: В случае повторного объявления чрезвычайного положения, при определении будущих мер, ограничивающих свободу передвижения, должны быть приняты во внимание рекомендации Конституционного суда БиГ (Решение АР 1217/20 от 22 апреля 2020 г.). ${ }^{2}$

- Институциям БиГ: Необходимо создать среду, благоприятствующую свободным СМИ в соответствии с основными демократическими принципами. В этом отношении следует учитывать рекомендации Уполномоченного по правам человека БиГ по защите здоровья журналистов.

- Институциям БиГ: В сотрудничестве с Агентством по защите личных данных БиГ необходимо предоставить четкие (письменные) инструкции по использованию личных данных во время кризисов.

- Институциям БиГ: Меры по организации местных выборов в ноябре 2020 года должны быть адаптированы к условиям пандемии и должно быть обеспечено необходимое финансирование. Необходимо гарантировать свободные избирательные кампании и равный доступ к общественности, как это определено в Законе о выборах.

- Гражданскому обществу: После пандемии необходимо определить экономические и финансовые потребности и приоритеты наиболее уязвимых слоев населения.

2 Конституционный суд пришел к выводу, что имело место нарушение свободы передвижения по статье II (3) (m) Конституции Боснии и Герцеговины и статье 2 Протокола № 4 к Европейской конвенции о защите прав человека и основных свобод в отношении запрета на передвижение лиц младше 18 лет и старше 65 лет на территории Федерации БиГ. 
- Гражданскому обществу: Во время кризисов следует взять на себя более динамичную функцию наблюдения, особенно в отношении случаев коррупции, а также в целях предотвращения нарушений прав человека.

\section{Применительно к Косово}

- $\quad E C$ : Следует избегать противоречивых сигналов внутри Союза по противоречивой теме территориального обмена между Косово и Сербией, поскольку они порождают политическую нестабильность и усиливают напряженность в регионе.

- $\quad E C$ : Косово должен быть предоставлен безвизовый режим без дальнейшего промедления.

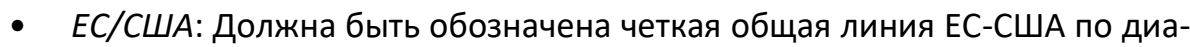
логу Белград-Приштина.

\section{Применительно к Черногории}

- Институциям Черногории: Роль парламента в контроле над действиями правительства должна быть вновь усилена, а контроль восстановлен, в частности, в отношении вопросов прав человека.

- Институциям Черногории: Требуется более быстрый ответ Верховного суда в отношении спорного вопроса, являются ли правительственные решения, принятые в ходе COVID-19, конституционными. Это, в частности, касается задержания лиц при ограничении свободы передвижения.

- Институциям Черногории: В соответствии со своей юрисдикцией омбудсмены должны более активно использовать свои полномочия в период пандемии и после пандемии для защиты и продвижения прав и свобод человека.

- Институциям Черногории: Следует уважать примат международного права над национальными законами, включая решения Европейского суда по правам человека, особенно в области защиты данных и конфиденциальности.

- Институциям Черногории: Следует разработать предполагающие участие всех, прозрачные стратегии реагирования на бедствия. Это должно включать тесное сотрудничество с организациями гражданского общества и развитие цифровых платформ, чтобы сделать государственные услуги более доступными. Уязвимые группы, в частности, нуждаются в активной информационной, экономической и социальной поддержке.

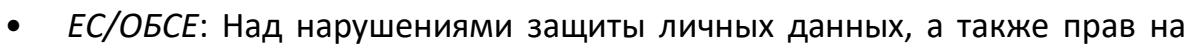
неприкосновенность частной жизни и демократических принципов, должен осуществляться более пристальный надзор. 
- $\quad E C$ : Следует поддержать выполнение рекомендаций по улучшению системы здравоохранения в Черногории, предоставленные некоммерческой организацией ECRI, и рекомендаций Комиссии EC в ее отчете по Черногории.

\section{Применительно к Северной Македонии}

- Парламенту Северной Македонии: Учитывая тот факт, что значительный процент правительственных постановлений не был напрямую связан с пандемией и что многие из них были признаны неконституционными, постановления правительства должны быть пересмотрены.

- Институциям Северной Македонии: Парламентские выборы следует проводить только при минимальном риске для здоровья населения. Все политические субъекты должны воздерживаться от использования пандемии COVID-19 в политических целях и должны стремиться к конструктивной роли в борьбе с кризисом.

- Институциям Северной Македонии: Должно быть проведено открытое обсуждение ограничений, налагаемых на права человека, перечисленных в Европейской конвенции, во время пика коронакризиса в Северной Македонии.

- Институциям Северной Македонии: Опыт с COVID-19 следует использовать для пересмотра системы антикризисного управления, чтобы создать эффективную и профессиональную систему с четкими обязанностями и потоком информации между участвующими учреждениями, а также протоколами и стандартными операционными процедурами.

- Институциям Северной Македонии: Следует инвестировать в медицинские материалы, оборудование и медицинский персонал, а также в цифровые инструменты для школ.

- $\quad$ EC/ правительству Северной Македонии: Процесс переговоров с Северной Македонией о членстве должен быть начат как можно скорее. Правительство страны-кандидата должно оставаться полностью приверженным европейским стандартам, верховенству закона и уважению прав и свобод человека даже во время кризисов.

\section{Применительно к Сербии}

- Политическому руководству Сербии: Политическое руководство должно четко заявить, что главная цель внешней политики - членство в ЕС. Следует избегать таких сигналов, как усиление внимания к другим центрам силы (например, Китаю и России) во время коронакризиса. Внутренняя и внешняя политика должна быть согласована с этой четкой ориентацией на ЕC.

- Комиссии EC: Учитывая, что Сербия определена Freedom House как «нелиберальная демократия», необходимо принимать гораздо боль- 
шее участие по вопросам, касающихся демократии. Перед сербским руководством следует сделать заявление о том, что членство в ЕС невозможно для полуавторитарного государства.

- $\quad$ Комиссии EC: Следует потребовать немедленного восстановления разделения властей, уважения свободы средств массовой информации и снижения уровня преступности и коррупции до социально приемлемого уровня.

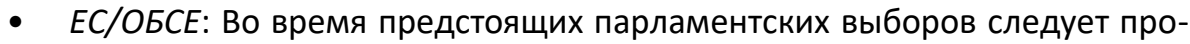
демонстрировать существенное взаимодействие с международными наблюдателями, потому что учитывая кризис и полуавторитарные условия, выборы не будут справедливыми.

- Сербскому правительству/ Косовскому правительству: Политический диалог должен быть продолжен как можно скорее. Следует избегать односторонних шагов, которые не способствуют достижению устойчивого соглашения. В этих переговорах следует использовать все возможности обоих обществ, чтобы избежать соглашения, которое может быть навязано гражданам с обеих сторон.

- EC/США: Необходимо снова найти единый трансатлантический голос, что имеет решающее значение для достижения окончательного соглашения о полной нормализации отношений между Белградом и Приштиной. Кроме того, обеим сторонам должен быть предложен четкий путь к полноправному членству в ЕС, а также помощь в преодолении антагонизма.

\section{Применительно ко всем странам $3 Б$}

- Правительствам 3Б, ЕС и СРС: Следует принять региональный подход к борьбе с пандемией COVID-19, особенно в области медицинского сотрудничества, общих правил в отношении деловых поездок, туристических поездок и поездок в других целях.

\section{Отказ от ответственности}

Выраженные здесь взгляды являются исключительно взглядами авторов и не отражают точку зрения Консорциума оборонных академий и институтов изучения безопасности ПрМ, участвующих организаций или редакторов Консорциума.

Издание Connections: The Quarterly Journal, том 19, 2020 осуществляется при поддержке правительства Соединенных Штатов. 